\title{
Is there a precursor to the Cretaceous normal superchron? New paleointensity and age determination from Liaoning province, northeastern China
}

\author{
Rixiang Zhu ${ }^{\mathrm{a}, *}$, Ching-Hua Lo ${ }^{\mathrm{b}}$, Ruiping Shi ${ }^{\mathrm{a}}$, Yongxin Pan ${ }^{\mathrm{a}}$, \\ Guanghai Shi ${ }^{\mathrm{a}}$, Jian $\mathrm{Shao}^{\mathrm{c}}$ \\ a Institute of Geology and Geophysics, Chinese Academy of Sciences, Beijing 100029, China \\ b Department of Geosciences, National Taiwan University, 245 Choushan Road, Taipei 106, China \\ c Department of Geology, Peking University, Beijing 100871, China
}

Received 13 October 2003; received in revised form 12 January 2004; accepted 21 June 2004

\begin{abstract}
Although the geomagnetic reversal record for the past $160 \mathrm{Myr}$ is relatively well documented, whether a precursor exists before the onset of the Cretaceous normal superchron (CNS) remains a contentious topic in the study of the evolution of geomagnetic reversals. In the present study we have tried to find out if new paleointensity data can provide more information about this topic. A paleointensity, geochronologic and paleomagnetic investigation has been conducted on four andesitic basalt lava flows from Hulahada in Liaoning Province, northeastern China. Radiometric ${ }^{40} \mathrm{Ar} /{ }^{39} \mathrm{Ar}$ dating experiments indicate the volcanism occurred at about $122.7 \pm 0.6 \mathrm{Myr}$, corresponding to marine anomaly Mln. Thermomagnetic experiments and hysteresis loops show that the main magnetic carrier of remanence are titanomagnetites with Curie temperatures of $\sim 580^{\circ} \mathrm{C}$. Thirty-eight samples from three lavas underwent Thellier-Thellier paleointensity experiments with systematic partial thermoremanent magnetization (pTRM) checks. Ten samples from the studied lavas yield reliable paleointensity estimates with a mean virtual dipole moment $\left(\mathrm{VDM}^{*}\right)$ of $(4.8 \pm 0.2) \times 10^{22} \mathrm{Am}^{2}$, about half the strength of the modern-day field. Our paleointensity results in conjunction with previous data suggest that there is no precursor to the CNS.
\end{abstract}

(C) 2004 Elsevier B.V. All rights reserved.

Keywords: Paleointensity; ${ }^{40} \mathrm{Ar} /{ }^{39} \mathrm{Ar}$ dating; Cretaceous normal superchron; Andesitic basalt

\footnotetext{
* Corresponding author. Tel.: +86 1062007912 ; fax: +861062010846 .

E-mail address: rxzhu@mail.igcas.ac.cn (R. Zhu).
}

\section{Introduction}

The reversal sequence of Earth's magnetic field contains information about core processes (McFadden and Merrill, 1984), which appealed many geophysicists beyond the field of geomagnetism or paleomag- 


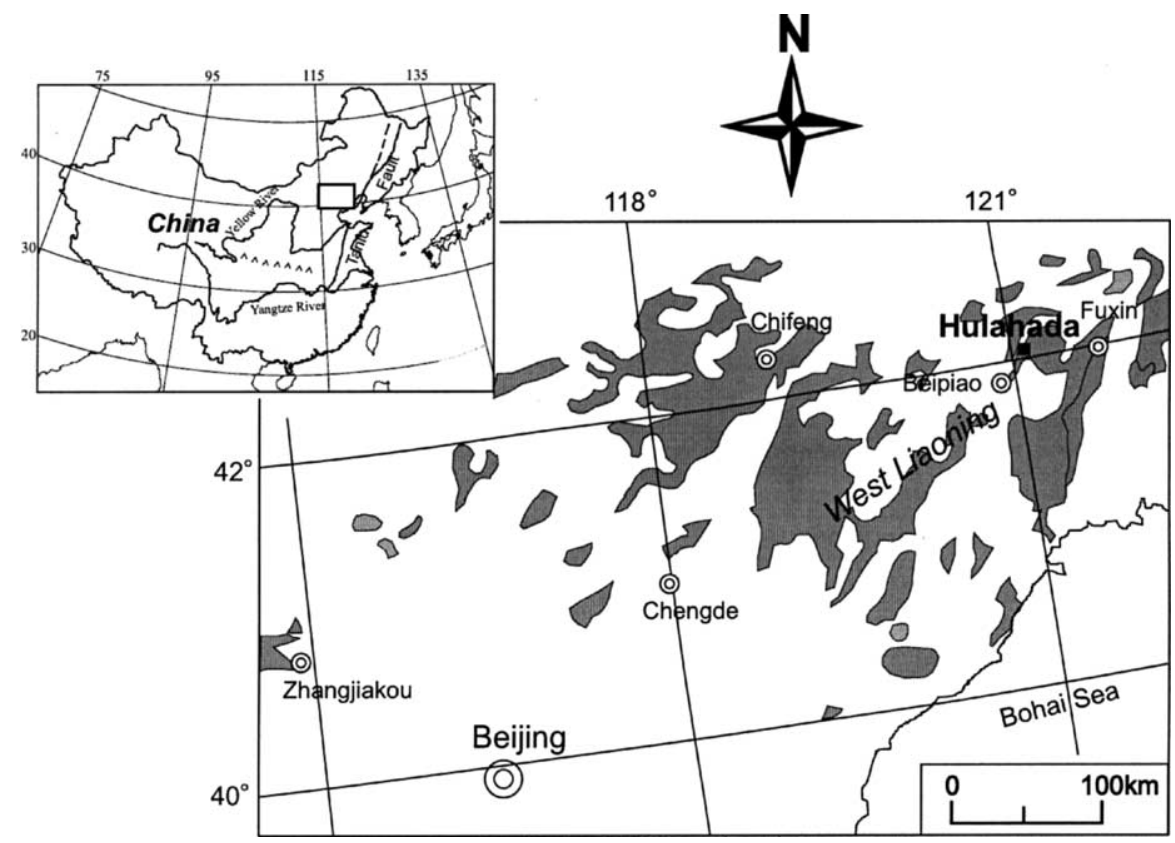

Fig. 1. Schematic map showing Cretaceous rock distribution in studied area and the sampling site of Hulahada section (redrafted from Zhu et al., 2003).

netism (Gallet and Courtillot, 1995). Indeed, long-term changes in geomagnetic reversal frequency may reflect some forms of core-mantle coupling (Courtillot and Besse, 1987). There are two dominant views regarding the statistical characterization of the geomagnetic reversal rate preceding the Cretaceous normal superchron (CNS), which have quite different implications for the geodynamo. The first one, McFadden and Merrill (1984, 2000), suggests a long-term thermal influence of mantle convection on core dynamics led to a gradually decrease of the reversal rate down to 4.5 times per million years between 160 and $118 \mathrm{Myr}$. In that case, it seems that the occurrence of the CNS could be predicted. The second view, supported by Gallet and Hulot (1997) and Hulot and Gallet (2003), describes a stationary reversal rate process up to the CNS suggesting the later could represent a sudden non-linear transition between a reversing and a non-reversing state of the geodynamo. Those authors proposed that the occurrence of the Mln, 3 Myr before the onset of this superchron, could be identified as a precursor possibly accorded to medium-term changes (10 Myr time scale) in the core-mantle boundary conditions. They noted, however, that the sole analysis of the reversal rate does not allow this assumption to be tested. With this respect, no doubt that obtaining reliable intensity data for the period of pre-CNS, especially during the Mln would be of particular interest.

In this paper we first present new paleointensity results from Hulahada volcanic rocks $\left(42.1^{\circ} \mathrm{N}, 121.5^{\circ} \mathrm{E}\right)$ (Fig. 1) erupted at $\sim 122.7 \pm 0.6 \mathrm{Myr}$ in order to clarify whether Mln is a real precursor of the occurrence of the CNS or not.

\section{Geological setting and dating}

\subsection{Geological setting and sampling}

The Hulahada section $\left(42.1^{\circ} \mathrm{N}, 121.5^{\circ} \mathrm{E}\right)$ is located in the northwestern part of the Fuxin Basin (Fig. 1). Previous paleomagnetic investigation has demonstrated that although regional deformation occurred since Early Cretaceous, no significant latitudinal placement was revealed (Zhu et al., 2004). This site has attracted the attention of geoscientists because of its wellpreserved and unique Early Cretaceous fossil assemblages, known as Jehol fauna, in its sedimentary strata 
(Pan et al., 2001; Zhou et al., 2003). The studied section is composed of andesitic basalt placed on the lowermost part of the Tuhulu Formation. The section is overlain by sandstone and shale in which the fossil assemblages (Lycoptera-davidi, Sphalrum sp., Ferganoconcha sp., Prolaicalia sp.) are preserved (Bureau of Geology and Mineral Resources of Liaoning, 1971). So far no radiometric dating has been reported on those volcanic rocks. Four lava flows (labeled downward) forming a continuous 55-m thick sequence are well exposed along a gully, and no sedimentary layers are observed between them. Horizons with some bubbles or weathered horizon in violet colors were used to distinguish the different flows in the field. At least eleven fresh cores were taken using a portable gasoline-powered drill at each lava flow ( 55 orientated cores in total). Cores were then orientated in most case with both magnetic and sun compasses.

\subsection{Radiometric dating}

Although fresh massive sample was collected from each lava flow for radiometric dating, microscope examination showed that only the sample FH06 from lava \#1 was suitable for ${ }^{40} \mathrm{Ar} /{ }^{39} \mathrm{Ar}$ dating. Other samples presented very fine-grained texture as well as pervasive alteration. These problems could lead to various artifacts (recoil, argon loss) and consequently biased ages. The whole-rock sample FH06 was dated using the ${ }^{40} \mathrm{Ar} /{ }^{39} \mathrm{Ar}$ laser step-heating method. The sample was first crushed and disintegrated. After sieving, rock chips with size in the range of 140-250 $\mu \mathrm{m}$ were ultrasonically cleaned in distilled water, dried, and then handpicked to remove visible contamination. The sample was then irradiated together with the LP-6 biotite standard (Odin et al., 1982) giving a ${ }^{40} \mathrm{Ar} /{ }^{39} \mathrm{Ar}$ age of $128.4 \pm 0.2 \mathrm{Myr}$ calibrated according to the age of the Fish Canyon biotite (Baksi et al., 1996) in the VT$\mathrm{C}$ position at the THOR Reactor in Taiwan for $30 \mathrm{~h}$. After irradiation, standards were fused using a doublevacuum Mo furnace and samples were incrementally heated using a US LASER Nd-YAG operated in continuous mode. The gas was then measured by a VG3600 mass spectrometer at the National Taiwan University. Age was calculated from Ar isotopic ratios measured after corrections for mass discrimination, interfering nuclear reactions, procedural blanks, and atmospheric Ar contamination. Detail of analysis and data process- (a) FH06 Whole Rock

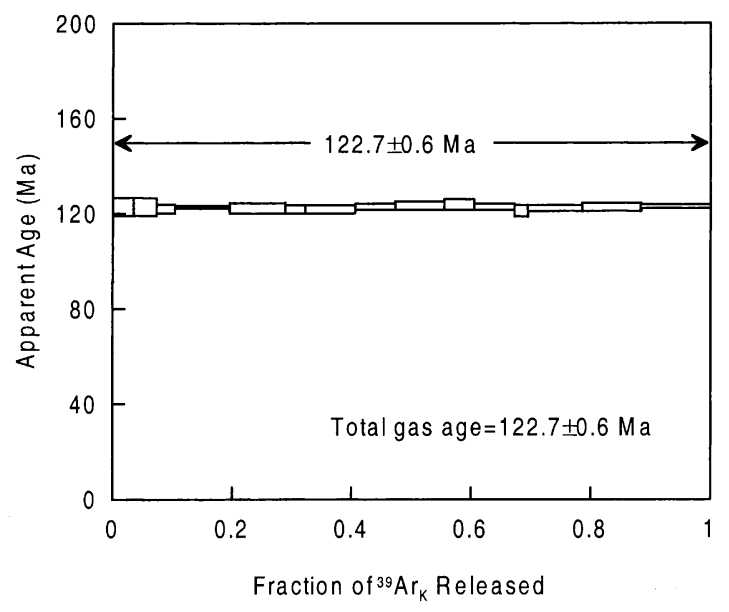

(b) FH06 Whole Rock

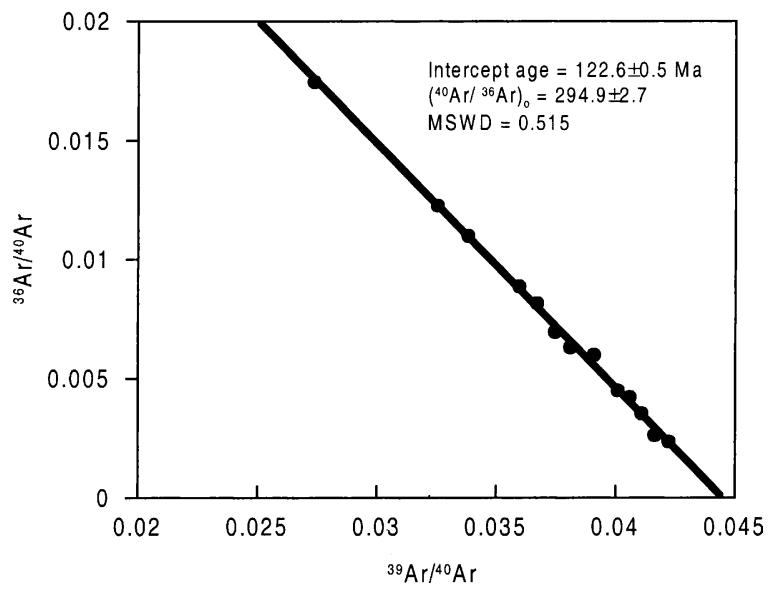

Fig. 2. ${ }^{40} \mathrm{Ar} /{ }^{39} \mathrm{Ar}$ age spectrum plot for sample FH06 taken from lava \#1.

ing procedures are outlined in Lo et al. (2002). The results of the ${ }^{40} \mathrm{Ar} /{ }^{39} \mathrm{Ar}$ experiments are shown in Table 1 and plotted as age spectrum and isotope correlation diagrams in Fig. 2.

As shown in Fig. 2a, the studied sample exhibits a flat profile for the age spectra, with a plateau age of $122.7 \pm 0.6 \mathrm{Myr}$. The plateau age is consistent with its respective intercept ages obtained from the isotope correlation diagram, $122.6 \pm 0.5 \mathrm{Myr}$ (Fig. 2b). Regression of the data on an isotope correlation diagram indicates that the non-radiogenic argon component in the sample is mainly atmospheric, as indicated by the 
Table 1

Results of ${ }^{40} \mathrm{Ar} /{ }^{39} \mathrm{Ar}$ laser step-heating experiments

\begin{tabular}{|c|c|c|c|c|c|c|c|}
\hline$E^{\mathrm{a}}$ & Atm. (\%) & ${ }^{36} \mathrm{Ar} /{ }^{39} \mathrm{Ar}$ & ${ }^{37} \mathrm{Ar} /{ }^{39} \mathrm{Ar}$ & ${ }^{38} \mathrm{Ar} /{ }^{39} \mathrm{Ar}$ & ${ }^{40} \mathrm{Ar} /{ }^{39} \mathrm{Ar}$ & ${ }^{40} \mathrm{Ar} /{ }^{36} \mathrm{Ar}$ & Age (Ma) \\
\hline 0.11 & 38.54 & $0.47934 \mathrm{E}-01$ & $0.12784 \mathrm{E}+01$ & $0.21559 \mathrm{E}-01$ & $0.36530 \mathrm{E}+02$ & $0.76208 \mathrm{E}+03$ & $122.9 \pm 3.5$ \\
\hline 0.22 & 15.62 & $0.14350 \mathrm{E}-01$ & $0.89660 \mathrm{E}+00$ & $0.21699 \mathrm{E}-01$ & $0.26744 \mathrm{E}+02$ & $0.18637 \mathrm{E}+04$ & $123.4 \pm 2.9$ \\
\hline 0.34 & 19.65 & $0.18812 \mathrm{E}-01$ & $0.13465 \mathrm{E}+01$ & $0.22825 \mathrm{E}-01$ & $0.27803 \mathrm{E}+02$ & $0.14779 \mathrm{E}+04$ & $122.3 \pm 1.4$ \\
\hline 0.41 & 24.40 & $0.24792 \mathrm{E}-01$ & $0.14285 \mathrm{E}+01$ & $0.24086 \mathrm{E}-01$ & $0.29606 \mathrm{E}+02$ & $0.11942 \mathrm{E}+04$ & $122.5 \pm 0.8$ \\
\hline 0.51 & 27.19 & $0.28617 \mathrm{E}-01$ & $0.13905 \mathrm{E}+01$ & $0.24373 \mathrm{E}-01$ & $0.30745 \mathrm{E}+02$ & $0.10743 \mathrm{E}+04$ & $122.5 \pm 1.0$ \\
\hline 0.60 & 9.54 & $0.82771 \mathrm{E}-02$ & $0.12611 \mathrm{E}+01$ & $0.17774 \mathrm{E}-01$ & $0.24682 \mathrm{E}+02$ & $0.29820 \mathrm{E}+04$ & $122.2 \pm 1.2$ \\
\hline 0.71 & 18.13 & $0.17045 \mathrm{E}-01$ & $0.13082 \mathrm{E}+01$ & $0.21251 \mathrm{E}-01$ & $0.27268 \mathrm{E}+02$ & $0.15998 \mathrm{E}+04$ & $122.2 \pm 1.0$ \\
\hline 0.83 & 10.10 & $0.88297 \mathrm{E}-02$ & $0.11846 \mathrm{E}+01$ & $0.21201 \mathrm{E}-01$ & $0.24970 \mathrm{E}+02$ & $0.28280 \mathrm{E}+04$ & $122.8 \pm 1.1$ \\
\hline 0.92 & 14.05 & $0.12813 \mathrm{E}-01$ & $0.13025 \mathrm{E}+01$ & $0.22982 \mathrm{E}-01$ & $0.26274 \mathrm{E}+02$ & $0.20505 \mathrm{E}+04$ & $123.5 \pm 1.0$ \\
\hline 0.99 & 5.84 & $0.50029 \mathrm{E}-02$ & $0.10298 \mathrm{E}+01$ & $0.20808 \mathrm{E}-01$ & $0.24034 \mathrm{E}+02$ & $0.48041 \mathrm{E}+04$ & $123.8 \pm 1.7$ \\
\hline 1.15 & 7.75 & $0.66918 \mathrm{E}-02$ & $0.12415 \mathrm{E}+01$ & $0.21294 \mathrm{E}-01$ & $0.24343 \mathrm{E}+02$ & $0.36378 \mathrm{E}+04$ & $122.9 \pm 0.9$ \\
\hline 1.23 & 13.37 & $0.11910 \mathrm{E}-01$ & $0.13231 \mathrm{E}+01$ & $0.25180 \mathrm{E}-01$ & $0.25606 \mathrm{E}+02$ & $0.21499 \mathrm{E}+04$ & $121.4 \pm 1.7$ \\
\hline 1.30 & 8.28 & $0.71490 \mathrm{E}-02$ & $0.13130 \mathrm{E}+01$ & $0.20358 \mathrm{E}-01$ & $0.24351 \mathrm{E}+02$ & $0.34063 \mathrm{E}+04$ & $122.2 \pm 0.7$ \\
\hline 1.45 & 8.24 & $0.70634 \mathrm{E}-02$ & $0.10591 \mathrm{E}+01$ & $0.19945 \mathrm{E}-01$ & $0.24405 \mathrm{E}+02$ & $0.34551 \mathrm{E}+04$ & $122.5 \pm 1.0$ \\
\hline 1.54 & 5.39 & $0.46086 \mathrm{E}-02$ & $0.11232 \mathrm{E}+01$ & $0.20121 \mathrm{E}-01$ & $0.23708 \mathrm{E}+02$ & $0.51444 \mathrm{E}+04$ & $122.7 \pm 0.7$ \\
\hline
\end{tabular}

$J$-value: weighted mean of three fusions of irradiation standard LP-6 Biotite having a calibrated ${ }^{40} \mathrm{Ar} /{ }^{39} \mathrm{Ar}$ age of $128.4 \pm 0.2 \mathrm{Ma}$, based on Fish Canyon Sanidine (28.02 $\pm 0.28 \mathrm{Ma}$ ) (Baksi et al., 1996; Renne et al., 1998). $J$-value $=0.00313916 \pm 0.00001318$. Age $(\mathrm{Ma})=$ the age calculated using the following decay constants: $\lambda_{\varepsilon}=0.581 \times 10^{-10}$ year $^{-1} ; \lambda_{\beta}=4.962 \times 10^{-10}$ year $^{-1} ; \lambda=5.543 \times 10^{-10}$ year $^{-1} ;{ }^{40} \mathrm{~K} / \mathrm{K}=$ 0.01167 atom\% (Steiger and Jäger, 1977). Total gas age $=122.7 \pm 0.6 \mathrm{Ma}$, plateau age $=122.7 \pm 0.6 \mathrm{Ma}(0.11-1.54 \mathrm{~W})$. The quoted error is one standard deviation and includes the error in the standard error, but doesn't include the error in the interference corrections.

${ }^{\text {a }}$ Laser energy in watt.

obtained $\left({ }^{40} \mathrm{Ar} /{ }^{36} \mathrm{Ar}\right)_{0}$ value $(294.9 \pm 2.7$ with MSWD $=0.515)$ which is perfectly consistent with the atmospheric composition (Fig. 2b). This would suggest that the obtained plateau age should estimate the eruption age for the lava flow.

\section{Rock-magnetic investigations and magnetic field vector determinations}

\subsection{Rock-magnetic investigations}

To ensure the thermal stability of the samples during successive heating in the laboratory and in order to identify the magnetic carriers of magnetic remanence, thermomagnetic properties of both temperature dependence of low-field susceptibility, $\kappa(T)$ and that of magnetization, $J(T)$ were investigated in argon atmosphere on four specimens distributed between each lava flow. Both $\kappa(T)$ and $J(T)$ curves were measured on specimens from the same sampled core in order to better compare results. $\kappa(T)$ curves (Fig. 3a) were obtained by heating small amounts of powdered samples from each flow up to $600{ }^{\circ} \mathrm{C}$ in argon atmosphere using a KLY-3 device with heating and cooling rates about $10^{\circ} \mathrm{C} \min ^{-1} . J-T$ curves (Fig. 3b) were conducted by heating small amounts of powdered samples from each flow up to $700{ }^{\circ} \mathrm{C}$ in a steady field of $200 \mathrm{mT}$ and in argon atmosphere on a Magnetic Measurements Variable Field Translation Balance with the same heating and cooling rates, $10^{\circ} \mathrm{C} \mathrm{min}^{-1}$. All these investigations were conducted at the Paleomagnetism Laboratory of the Institute of Geology and Geophysics (PaleoLabIGG), Chinese Academy of Sciences. Both $\kappa(T)$ and $J-T$ curves can be generally divided into two types. The first type (75\%) has only one stable Curie temperature $\sim 580^{\circ} \mathrm{C}$ (e.g. lava \#1, \#2, \#4), indicative of Ti-poor titanomagnetite, and shows at most a minor amount of irreversibility during the heating and cooling cycle. This type is suitable for paleointensity determination. The other type (e.g. lava \#3), however, displays irreversible behavior characterized by a significant drop in magnetization between $\sim 200-400{ }^{\circ} \mathrm{C}$. And a second drop near $500^{\circ} \mathrm{C}$ in the heating curve (Fig. 3). Other $J-T$ curves of lava \#3 samples are presented in Fig. 4 a. The magnetization drops before $400^{\circ} \mathrm{C}$ possibly correspond to a breakdown of maghemite. This indicates that lava \#3 may be not suitable for paleointensity determination, and thus it was excluded in such experiments. 

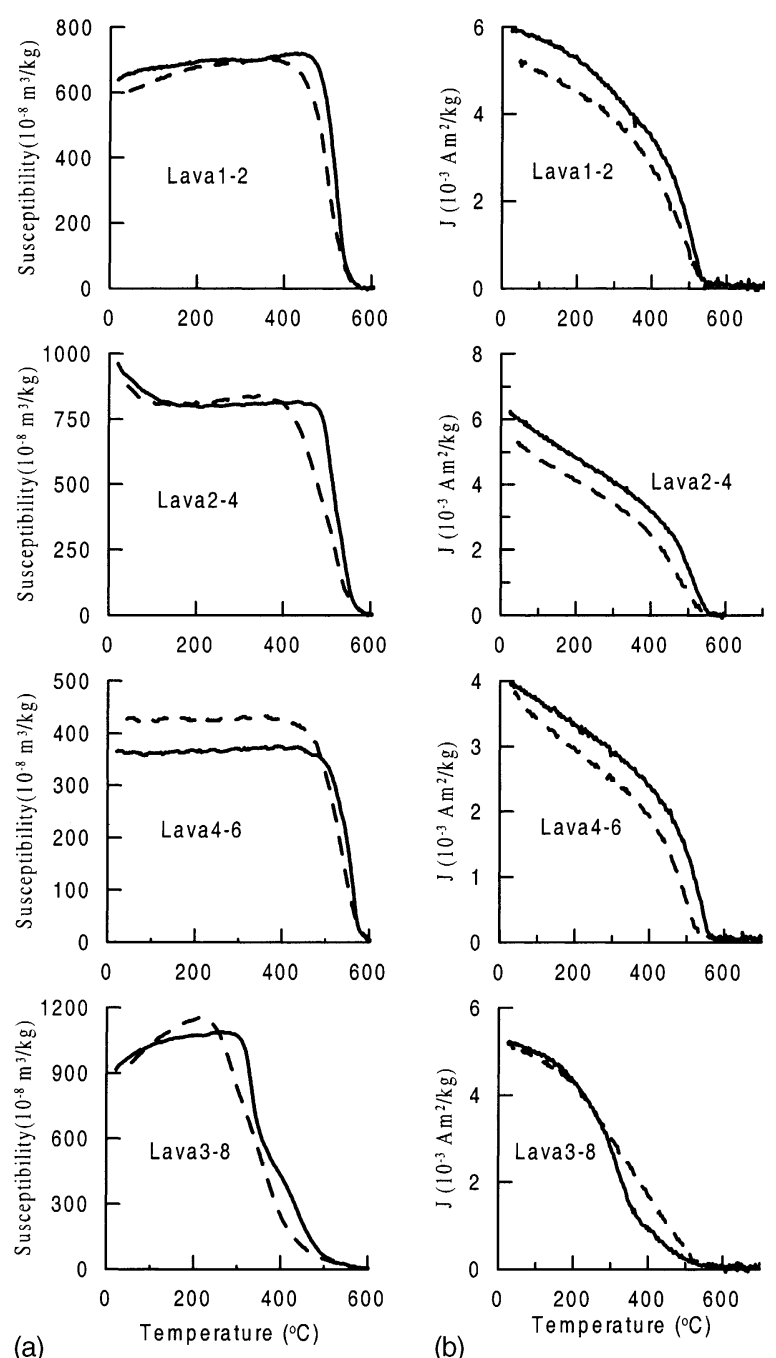

(b)

Fig. 3. Representative $\kappa-T$ (a) and $J-T$ (b) curves from this study. Solid and dashed lines stand for the heating and cooling curves, respectively.

Using a MicroMag 2900 alternating gradient force magnetometer, measurements of magnetic hysteresis loops and stepwise backfield demagnetization of saturated isothermal remanence was conducted on small chips from each lava. A hysteresis loop of maximum field of $300 \mathrm{mT}$ (inside in Fig. 5a) and demagnetization of saturated isothermal remanence obviously show that the titianomagnetite is dominant in the studied samples (Fig. 5b). After removal of a small paramagnetic contribution values of parame- ters Hc, Ms, and Mrs were obtained for all measured samples. A typical value was shown in Fig. 5b. It shows that magnetic carriers of these rocks are PSD (pseudo-single domain) grains. However, the room temperature hysteresis parameters have limited resolution in estimating domain state of most natural rocks (Goguitchaichvili et al., 2001a,b). Thus we did not use these data to select samples for Thellier paleointensity experiments.

\subsection{Paleodirectional results}

At least eight samples from each site were subjected to thermal or alternating field (AF) demagnetization. In most cases stepwise thermal demagnetization up to $585^{\circ} \mathrm{C}$ with temperature intervals of $25-50{ }^{\circ} \mathrm{C}$ was performed for paleodirectional determination using a Magnetic Measurements Thermal Demagnetizer with a residual magnetic field less than $10 \mathrm{nT}$. Remanence measurements were conducted on a JR-5A spinner magnetometer. AF demagnetization up to $70 \mathrm{mT}$ with intervals of 5-10 $\mathrm{mT}$ and remanence measurements were carried out on a 2G-755 apparatus with degaussing system. Both magnetometers were installed in the shielded room $(<300 \mathrm{nT})$ of the PaleoLab-IGG. Totally 34 and 10 samples were subjected thermal and AF demagnetization, respectively. The majority of the samples ( 35 out of 44 ) are characterized by a stable component isolated after demagnetization to a peak temperature of only $170^{\circ} \mathrm{C} / 200^{\circ} \mathrm{C}$ or a peak field of $15 \mathrm{mT}$. The direction of characteristic remanent magnetization (ChRM) for each sample was determined by the method of principal component analysis (Kirschvink, 1980) and then averaged for each site (Fisher, 1953; McFadden and McElhinny, 1988). Although samples of lava \#3 may be not suitable for paleointensity experiments, ChRMs were revealed after demagnetization to a peak temperature of only $200^{\circ} \mathrm{C}$ or a peak field of $15 \mathrm{mT}$ (Fig. 4b). The site-mean direction was calculated using standard Fisher statistics (Fisher, 1953). The results show that all four flows possess normal polarity with an average direction, $D / I=3.1^{\circ} / 59.8^{\circ}\left(\alpha_{95}\right.$ $=4.6^{\circ}$ ) and corresponding paleomagnetic pole position of Plat $=87.6^{\circ}$, Plong $=218.2^{\circ}$ (Table 2). The mean directions of adjacent individual flows passed $F$ test at 95\% confidence (McFadden and Lowes, 1981) indicating that the eruption of these four lavas is timeindependent. 

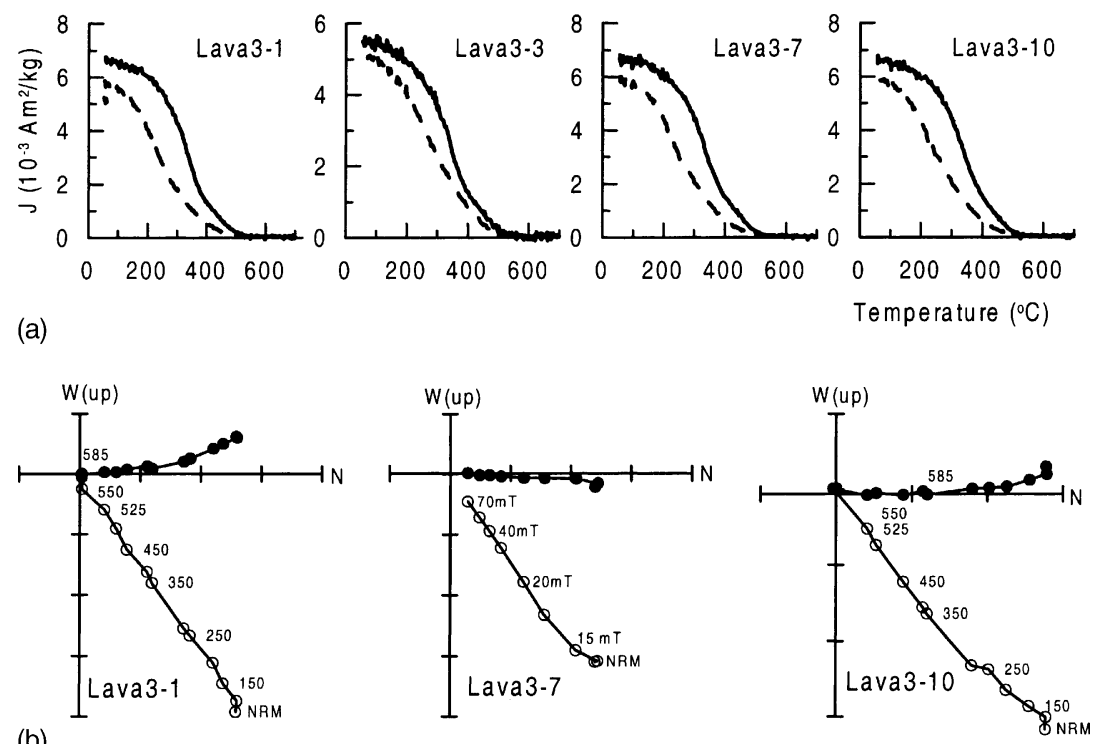

Fig. 4. Thermomagnetic curves determined from different horizontal levels from lava \#3 (a), solid (dashed) lines stand for the heating (cooling) curves, respectively. Thermal or AF demagnetization diagrams (b), the filled (open) symbols refer to the horizontal (vertical) plane.

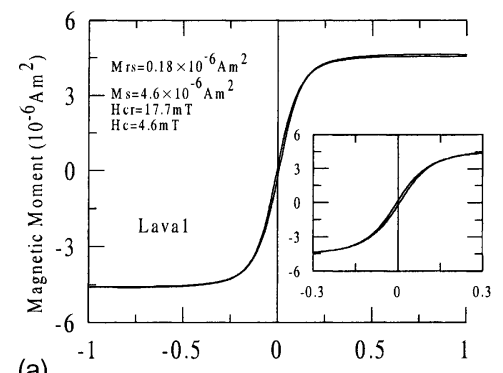

(a)

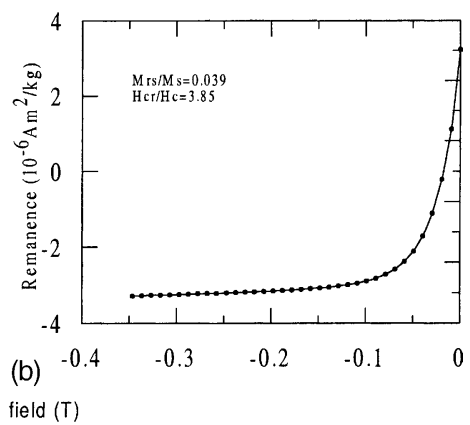

Fig. 5. Example of hysteresis loop plotted with a maximum field of IT (left) and $300 \mathrm{mT}$ (inside).

\subsection{Thellier's experiments}

On the basis of the paleodirectional results and the thermomagnetic analyses of both $\kappa(T)$ and $J-T$ curves, samples were selected for the paleointensity experiments. Samples were selected if they indicated an easily removable secondary overprint and its ChRM direction agrees to the flow mean direction. And thermomagnetic behavior was characterized by a single high Curie temperature and "pseudo-reversible" heating and cooling curves (e.g. Coe et al., 1984; Laj et al., 1997). Total 38 samples from lava 1, 2 and 4, therefore, were selected for paleointensity determination. The double heating paleointensity method of Coe (1967), modification of the Thellier and Thellier method (1959) was employed in the present study. All heating and cooling cycles were made in an argon environment and the remanence measurements were conducted using a JR$5 \mathrm{~A}$ spinner magnetometer situated in the shielded room $(<300 \mathrm{nT})$ at the PaleoLab-IGG. The intensity of the laboratory field for heating and cooling steps was $20 \mu \mathrm{T}$ and this was held to a precision better than $0.1 \mu \mathrm{T}$. Also, a few milligrams of activated charcoal was introduced into the furnace prior to each run to act as a 
Table 2

Paleodirectional results presented correspond to ChRM data

\begin{tabular}{lrllrlll}
\hline Lava & $n / N$ & $\begin{array}{l}\text { Dec } \\
\left({ }^{\circ}\right)\end{array}$ & $\begin{array}{l}\text { Inc } \\
\left({ }^{\circ}\right)\end{array}$ & \multicolumn{1}{l}{$k$} & $\begin{array}{l}\alpha_{95} \\
\left(^{\circ}\right)\end{array}$ & $\begin{array}{l}\text { PLA } \\
\left({ }^{\circ}\right)\end{array}$ & $\begin{array}{l}\text { PLO } \\
\left({ }^{\circ}\right)\end{array}$ \\
\hline 1 & $8 / 10$ & 7 & 58.8 & 150.3 & 4.5 & 84.4 & 225.5 \\
2 & $8 / 11$ & 0.2 & 62.8 & 179.3 & 4.1 & 86.9 & 124.1 \\
3 & $13 / 15$ & 358 & 55.6 & 33.4 & 7.3 & 84.8 & 319.6 \\
4 & $6 / 8$ & 7.8 & 61.7 & 264.3 & 4.1 & 83.9 & 191.8 \\
Mean & & 3.1 & 59.8 & 395.6 & 4.6 & 87.6 & 218.2
\end{tabular}

Note: $n / N$, number of samples (35) used in the paleodirection calculation/total number (44) demagnetized; Dec/Inc, declination/inclination; $k / \alpha_{95}$, precise parameter/radius of circle of the $95 \%$ confidence about the direction; PLA/PLO, VGP latitude/longitude. The latitude/longitude of the site is $42.1^{\circ} \mathrm{N} / 121.5^{\circ} \mathrm{E}$.

buffer to any oxidation/reduction of magnetite (Laj and Kissel, 1999). Above $250^{\circ} \mathrm{C}$, pTRM checks with steps of $250,360,400,430,460$ and $500^{\circ} \mathrm{C}$ were performed in order to detect any possible magnetomineralogical changes occurring during heating. Temperature reproducibility between two steps was in general better than $2^{\circ}$. The highest temperature used in the Thellier experiment was $525^{\circ} \mathrm{C}$ with typical temperature intervals of $25-50{ }^{\circ} \mathrm{C}$.

Examples of the accepted paleointensity results and associated orthogonal diagrams are shown in Fig. 6. Associated orthogonal diagrams in Fig. 6 show that the NRM derived from the Thellier-Thellier experiments do not bias toward the direction of the applied field. The ChRMs obtained were always virtually identical to that of sister samples used for paleodirectional determinations. Because the ChRMs depend only on the demagnetization of the NRM and not on the acquisition of the TRM, the ChRM can be isolated even if on reliable paleointensity is obtained from the Thellier-Thellier experiments. NRM-TRM data were taken for paleointensity determination in the interval in which the Arai plot remained linear and that the pTRM-checks remained positive. A given pTRM-check was considered negative if its value differed from the initial value associated with that peak temperature by more than $3 \%$. Of the 38 studied samples, 10 samples from three lavas yield reliable paleointensity results and 28 samples have been discarded because of their failure in the pTRM-checks. The quality of each paleointensity determination was evaluated using the statistical parameters developed by Coe et al. (1978) (Table 3). As can be seen in Table 3, the values of NRM fraction $(f)$, defined by the percent-
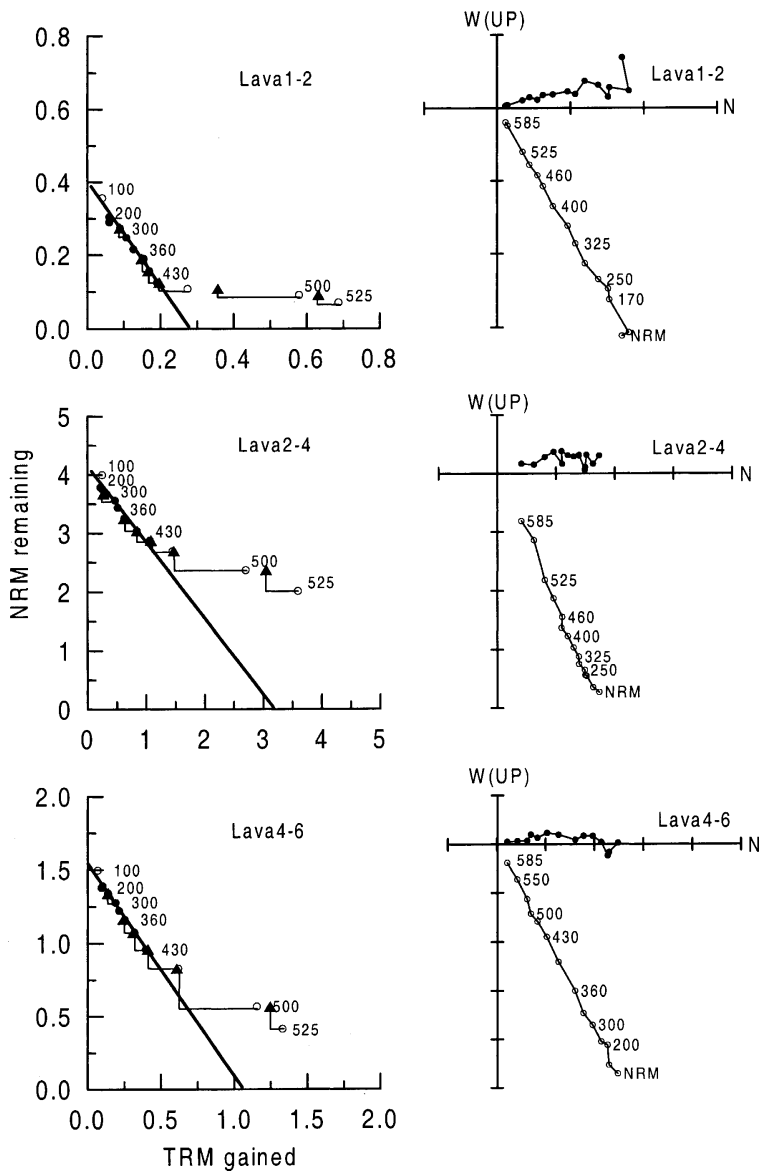

Fig. 6. Examples of NRM-TRM plots (left) and orthogonal projections of the associated NRM demagnetization (right) for Hulahada samples. In the NRM-TRM plots, filled (open) circles denote data points accepted (rejected) from the best-fit line used to define the Paleointensity values, solid triangles are pTRM checks. In the orthogonal diagrams, the filled (open) symbols refer to the horizontal (vertical) plane.

age of the NRM taken into account for the paleointensity determination, for most samples is larger than 0.4 and associated standard deviation is less than $6 \%$ of its paleointensity. The allegorical mean paleointensity values for these three flows range from 27.5 to $29.0 \mu \mathrm{T}$, and the corresponding $\mathrm{VDM}^{*}$ values range from $4.8 \times$ $10^{22}$ to $4.9 \times 10^{22} \mathrm{Am}^{2}$. The mean VDM determined from all three lava flows is $(4.8 \pm 0.2) \times 10^{22} \mathrm{Am}^{2}$ (see Table 3). It should be noted that the mean VDM mentioned above is not necessarily free of effects caused by an insufficiently averaged paleosecular variation be- 
Table 3

Paleointensity results

\begin{tabular}{|c|c|c|c|c|c|c|c|c|c|c|c|}
\hline Samples & Tint & $n$ & $f$ & Gap & $q$ & $F$ & $\sigma$ & $F_{\mathrm{a}}$ & $\sigma_{\mathrm{a}}$ & $\mathrm{VDM}^{*}$ & $\sigma_{\mathrm{VDM}}$ \\
\hline Lava \#1-\#2 & $170-430$ & 8 & 0.468 & 0.847 & 8.048 & 26.5 & 1.3 & & & & \\
\hline Lava \#1-\#4 & $170-430$ & 8 & 0.225 & 0.83 & 3.691 & 22.8 & 1.2 & & & & \\
\hline Lava \#1-\#6 & $200-460$ & 8 & 0.49 & 0.852 & 15.12 & 32.2 & 0.9 & & & & \\
\hline Lava \#1-\#7 & $250-460$ & 7 & 0.452 & 0.826 & 9.817 & 28.3 & 1.1 & 27.5 & 1.1 & 4.8 & 0.2 \\
\hline Lava \#2-\#3 & $100-525$ & 12 & 0.48 & 0.851 & 28.55 & 32.1 & 0.5 & & & & \\
\hline Lava \#2-\#4 & $200-460$ & 8 & 0.573 & 0.834 & 19.91 & 28.2 & 0.7 & & & & \\
\hline Lava \#2-\#6 & $100-525$ & 12 & 0.476 & 0.859 & 20.13 & 26.8 & 0.5 & 29.0 & 0.7 & 4.8 & 0.1 \\
\hline Lava \#4-\#5 & $100-460$ & 10 & 0.427 & 0.865 & 7.285 & 31.5 & 1.6 & & & & \\
\hline Lava \#4-\#6 & $100-430$ & 9 & 0.488 & 0.855 & 18.63 & 26.7 & 0.6 & & & & \\
\hline Lava \#4-\#12 & $170-430$ & 8 & 0.281 & 0.821 & 7.89 & 28.9 & 0.8 & 29.0 & 1.0 & 4.9 & 0.2 \\
\hline Mean & & & & & & & & 28.5 & 0.9 & 4.8 & 0.2 \\
\hline
\end{tabular}

Note: Tint, temperature interval used; $n$, the number of NRM points used for paleointensity determination; $f$, the percentage of NRM used for paleointensity determination; gap, an index of how well the NRM-TRM points are distributed along a straight line segment; $q$, quality factor defined by function $|b| f g / \sigma(b)$ where $b$ is the slope and $\sigma(b)$ is its standard deviation (Coe et al., 1978); $F$ and $\sigma$, paleointensity estimate for individual samples and standard deviation with unit of $\mu \mathrm{T} ; F_{\mathrm{B}}$ and $\sigma_{\mathrm{a}}$, mean paleointensity for each lava and standard deviation with unit of $\mu \mathrm{T}$; $\mathrm{VDM}^{*}$ and $\sigma_{\mathrm{VDM}}$ : virtual dipole moment and standard error with unit of $10^{22} \mathrm{Am}^{2}$.

cause only three lava flows were measured, so that we signalized the virtual dipole moment as VDM*.

\section{Discussion and conclusion}

\subsection{The primary origin of magnetization}

Although a stable ChRM was obtained from the majority of samples, it is crucial to consider the origin of magnetization. As discussed before, thermomagnetic analysis shows that the remanence is mainly carried by Ti-poor titanomagnetite, which most probably results from high temperature oxyexsolution during the flow emplacement and indicates primary magnetization of thermoremanent origin (Dunlop and Özdemir, 1997; Goguitchaichvili et al., 2002). Thus, even though no fold and reversal tests are available, we conclude that the characteristic direction is most probably primary.

The averaged paleofield values obtained are not necessarily free from effects caused by insufficiently averaged paleosecular variation because only four timeindependent lava flows were measured. The fact that the mean VGP for these lava flows lies $\sim 10^{\circ}$ away from apparent polar wander paths of Eurasia in the same time interval (Besse and Courtillot, 2002) is attributed to local tectonic rotations (Zhu et al., 2004). However, no significant latitudinal placement was revealed within
95\% confidence and we conclude that it is reasonable to calculate the VDM.

\subsection{May a precursor occur preceding the CNS? Is there a precursor to the CNS?}

The precise ${ }^{40} \mathrm{Ar} /{ }^{39} \mathrm{Ar}$ dating of lava \#1 (sample FH06) indicated the eruption age for the lava flows at the Hulahada section occurred around $122.7 \pm 0.6 \mathrm{Myr}$. It corresponds to the early stage of Mln if Channell et al.'s (1995) geomagnetic polarity time scale is used.

No doubt that paleointensity data during Mln is necessary to identify whether Mln is a real precursor of the occurrence of CNS or not. We have, therefore, combined our new data with other three published paleointensity data inside Mln (Pick and Tauxe, 1993; Bol'shakov and Solodovnikov, 1983). It obtained an average value of $(3.8 \pm 0.9) \times 10^{22} \mathrm{Am}^{2}$. This is remarkably consistent with recently published paleointensity data just prior to or within the very beginning of the Cretaceous normal superchron from the northeastern China (Zhu et al., 2001, 2004). Using the modified Thellier method (Coe, 1967), the Zhuanchengzi section, dated to $120.93 \pm 0.88 \mathrm{Myr}$ and corresponding to M0 (Channell et al., 1995), yielded a mean VDM of $(4.0 \pm 0.1) \times 10^{22} \mathrm{Am}^{2}$ (Zhu et al., 2001). The Jianguo section, dated to $116.8 \pm 3.0 \mathrm{Myr}$, probably corresponding to the ISEA event obtained an average VDM 
of $(4.2 \pm 0.1) \times 10^{22} \mathrm{Am}^{2}$ (Zhu et al., 2004). Moreover, a mean VDM value of $3.5 \times 10^{22} \mathrm{Am}^{2}$ spanning 133-124 Ma has been obtained by Zhu et al. (2003). This has been confirmed by paleointensity determinations using the modified Shaw method and the new microwave technique (Pan et al., 2004). A review of available global paleointensity data covering the time interval between 165 and 120 Ma revealed a coherent trend, in which the average field intensity increases as the CNS is approached (see Zhu et al., 2003). In comparison with those data, the field intensity of Mln is well consistent with this general trend, contrarily to the behavior of the reversal rate mentioned by Hulot and Gallet (2003). Therefore, our paleointensity results suggest that Mln might be not a precursor preceding the CNS.

Although there is some doubt about the high paleointensity after the ISEA using the plagioclase crystals (Heller et al., 2002), a joint analysis of Tarduno et al.'s (2001) paleointensity data with geochronologic and paleomagnetic data (Zhu et al., 2004) indicates that a sudden increase in the Earth's magnetic field strength appears just after the ISEA, suggesting that the ISEA dated at $116.8 \pm 3.0 \mathrm{Myr}$ might be actually the beginning of the CNS. This probably attests for a random non-linear transition between reversing and non-reversing regimes of the geodynamo if the ISEA is considered the onset of the CNS. Indeed, documenting variation in the VDM of the geomagnetic field during the CNS has recently been the subject of considerable interest, not the least because a detailed and reliable VDM record would be much helpful to clarify the interpretation mentioned above. Such a record would provide an important information concerning issues related to geodynamo evolution, such as how the geomagnetic field responds to stage in superchron cycling. The published VDMs during the CNS are, however, characterized by large fluctuations (Tarduno et al., 2001, 2002; Pick and Tauxe, 1993; Juarez et al., 1998; Shcherbakov et al., 2002; Tanaka and Kono, 2002) thus inhibiting us from drawing any confident conclusions. But they met the strict criteria for paleointensity data quality, these determinations should be acknowledged as reliable. If so, it might be suggested that geomagnetic strength frequently fluctuated during the CNS, contrarily to the paleointensity pattern between the time intervals of 160-120 Ma.

\section{Acknowledgements}

The authors would like to thank Drs. Rob Coe and Manuel Calvo for their constructive suggestions. This work was supported by the National Science Foundation of China (40221402) and CAS (KZCX1-07).

\section{References}

Baksi, A.K., Archibald, D.A., Farrar, E., 1996. Intercalation of ${ }^{40} \mathrm{Ar} /{ }^{39} \mathrm{Ar}$ dating standards. Chem. Geol. 129, 307-324.

Besse, J., Courtillot, V., 2002. Apparent and true polar wander and the geometry of the geomagnetic field over the last $200 \mathrm{Myr}$. J. Geophys. Res. 107 (B11), 49-59.

Bol'shakov, A.S., Solodovnikov, G.M., 1983. Geomagnetic field intensity in Armenia in the Late Jurassic and Early Cretaceous. Izv. Acad. Sci. USSR Earth Phys. (Engl. Trans.) 19, 976-982.

Bureau of Geology and Mineral Resources of Liaoning, 1971. Regional Geology Map of Fuxin. First Group of Regional Geology Survey of Liaoning, pp. 1-77.

Channell, J., Erba, E., Nakanishi, M., Tamaki, K., 1995. In: Berggren, W., Kent, D., Aubry, M., Hardenbol, J. (Eds.), Geomagnetic Chronology, Time Scales and Stratigraphic Correlation, vol. 54. SEPM Spec. Publ, pp. 51-64.

Coe, R.S., 1967. Paleointensity of the earth's magnetic field determined from Tertiary and Quaternary rocks. J. Geophys. Res. 72, 3247-3262.

Coe, R.S., Grommé, C.S., Mankinen, E.A., 1978. Geomagnetic paleointensities from radiocarbon-dated lava flows on Hawaii and the question of the Pacific nondipole low. J. Geophys. Res. 83, 1740-1756.

Coe, R.S., Gromme, S., Mankinen, E.A., 1984. Geomagnetic paleointensity from excursion sequences in Lavas on Oahu, Hawaii. J. Geophys. Res. 89, 1059-1069.

Courtillot, V., Besse, J., 1987. Magnetic field reversals, polar wander, and core-mantle coupling. Science 237, 1140-1147.

Dunlop, D., Özdemir, Ö., 1997. Rock Magnetism. Cambridge University Press, p. 573.

Fisher, R.A., 1953. Dispersion on a sphere. Proc. R. Soc. Lond. Ser. A 217, 295-305.

Gallet, Y., Courtillot, V., 1995. Geomagnetic reversal behaviour since 100 Ma. Phys. Earth Planet. Inter. 92, 235-244.

Gallet, Y., Hulot, G., 1997. Stationary and non-stationary behaviour within the geomagnetic polarity time scale. Geophys. Res. Lett. $24,1875-1878$.

Goguitchaichvili, A.L., Alva-Valdivia, M., Rosas-Elguera, J., Urrutia-Fucugauchi, J., Gonzalez, J.A., Morales, J., Sole, J., 2002. An integrated paleomagnetic study of Rio Grande de Santiago volcanic succession (trans-Mexican volcanic belt): revisited. Phys. Earth Planet. Inter. 130 (3/4), 175-194.

Goguitchaichvili, A., Morales, J., Urrutia-Fucugauchi, J., 2001a. On the use of continuous thermomagnetic curves in paleomagnetism. C. R. Acad. Sci. Earth Planet. Sci. 333, 699-704. 
Goguitchaichvili, A., Alva-Valdivia, L.M., Urrutia-Fucugauchi, J., Zesati, C., Caballero, C., 2001b. Palaeomagnetic and palaeointensity study of Oligocene volcanic rocks from Chihuahua (northern Mexico). Phys. Earth Planet. Inter. 124, 223-236.

Heller, R., Merrill, R.T., McFadden, P.L., 2002. The variation of intensity of earth's magnetic field with time. Phys. Earth Planet. Inter. 131, 237-249.

Hulot, G., Gallet, Y., 2003. Do superchrons occur without any palaeomagnetic warning? Earth Planet. Sci. Lett. 210 (1/2), 191-201.

Juarez, M.T., Tauxe, L., Gee, J.S., Pick, T., 1998. The intensity of the Earth's magnetic field over the last 160 million years. Nature 394, 878-881.

Kirschvink, J.L., 1980. The least-squares line and plane and the analysis of paleomagnetic data. Geophys. J. R. Astron. Soc. 62, 699-718

Laj, C., Rais, A., Surmont, J., Gillot, P.-Y., GuiUou, H., Kissel, C., Zanella, E., 1997. Changes of the geomagnetic field vector obtained from lava sequences on the island of Vulcano (Aeolian Islands Sicily). Phys. Earth Planet. Inter. 99, 161-177.

Laj, C., Kissel, C., 1999. Geomagnetic field intensity at Hawaii for the last $420 \mathrm{kyr}$ from the Hawaii Scientific Drilling Project core, Big Island. Hawaii J. Geophys. Res. 104 (B7), 15317-15338.

Lo, C.-H., Chung, S.-L., Lee, T.-Y., Wu, G.-Y., 2002. Age of the Emeishan flood magmatism and relations to Permian-Triassic boundary events. Earth Planet. Sci. Lett. 198, 449-458.

McFadden, P.L., Merrill, R.T., 1984. Lower mantle convection and geomagnetism. J. Gephys. Res. 89 (B5), 3354-3362.

McFadden, P.L., Merrill, R.T., 2000. Evolution of the geomagnetic reversal rate since $160 \mathrm{Ma}$ : is the process continuous? J. Geophys. Res. 105, 28455-28460.

McFadden, P.L., Lowes, F.J., 1981. The discrimination of mean directions drawn from Fisher distributions. Geophys. J. R. Astron. Soc. 67, 19-33.

McFadden, P.L., McElhinny, F.J., 1988. The combined analysis of remagnetisation circles and direct observations in palaemagnetism. Earth Planet. Sci. Lett. 87, 161-172.

Odin, G.S., et al., 1982. Interlaboratory standards for dating purposes. In: Odin, G.S. (Ed.), Numerical Dating in Stratigraphy. Wiley, Chichester, pp. 123-149.

Pan, Y.X., Zhu, R.X., Shaw, J., Zhou, Y.X., 2001. Magnetic polarity ages of the fossil-bearing strata at the Sihetun Section West Liaoning: a preliminary result. Chinese Sci. Bull. 46, 680-684.
Pan, Y.X., Hill, M.J., Zhu, R.X., Shaw, J., 2004. Further evidence for low intensity of the geomagnetic field in the early Cretaceous time: using the modified Shaw method and microwave technique. Geophys. J. Int. 157, 553-564.

Pick, T., Tauxe, L., 1993. Geomagnetic paleointensities during the Cretaceous normal superchron measured using submarine basaltic glass. Nature 366, 238-242.

Renne, P.R., Swisher, C.C., Deino, A.L., Karner, D.B., Owens, T.L., DePaolo, D.J., 1998. Intercalibration of standards, absolute ages and uncertainties in ${ }^{40} \mathrm{Ar} /{ }^{39} \mathrm{Ar}$ dating. Chem. Geol. 145, $117-152$.

Shcherbakov, V.P., Solodovnikov, G.M., Sycheva, N.K., 2002. Variations in the geomagnetic dipole during the past 400 million years (Volcanic rocks). Izv. Phys. Solid Earth 38, 113-119.

Steiger, R.H., Jäger, E., 1977. Subcommission on geochronology: convention on use of decay constants in geo- and cosmochronology. Earth Planet. Sci. Lett. 36, 359-362.

Tanaka, H., Kono, M., 2002. Paleointensities from a Cretaceous basalt platform in Inner Mongolia, northeastern China. Phys. Earth Planet. Inter. 133, 147-157.

Tarduno, J.A., Cottrell, R.D., Smirnov, A.V., 2001. High geomagnetic intensity during the mid-Cretaceous from Thellier analyses of single plagioclase crystals. Science 291, 1779-1783.

Tarduno, J.A., Cottrell, R.D., Smirnov, A.V., 2002. The Cretaceous superchron geodynamo: observations near the tangent cylinder. Proc. Natl. Acad. Sci. 99, 14020-14025.

Thellier, E., Thellier, O., 1959. Sur I'intensite du champ magnetique terrestre dans le passe, historique et geologique. Ann. Geophys. $15,285-376$.

Zhou, Z.H., Barrett, P.M., Hilton, J., 2003. An exceptionally preserved lower Cretaceous ecosystem. Nature 421, 807-814.

Zhu, R.X., Pan, Y.X., Shaw, J., Li, D.M., Li, Q., 2001. Geomagnetic palaeointensity just prior to the Cretaceous Normal Superchron. Phys. Earth. Planet. Inter. 128 (1-4), 207-222.

Zhu, R.X., Hoffman, K.A., Pan, Y.X., Shi, R.P., Li, D.M., 2003. Evidence for weak geomagnetic field intensity prior to the Cretaceous normal superchron. Phys. Earth Planet. Inter. 136, 187-199.

Zhu, R.X., Hoffman, K.A., Nomade, S., Renne, P.R., Shi, R.P., Pan, Y.X., Shi, G.H., 2004. Geomagnetic paleointensity and direct age determination of the ISEA (M0r?) chron. Earth Planet. Sci. Lett. 217 (3/4), 285-295. 